ZOOLOGIA 28 (6): 725-738, December, 2011

doi: $10.1590 /$ S1984-46702011000600005

\title{
Spatial diversity patterns of birds in a vegetation mosaic of the Pantanal, Mato Grosso, Brazil
}

\author{
Cleiton Adriano Signor ${ }^{1,2} \&$ João Batista Pinho'
}

\author{
1 Programa de Pós-Graduação em Ecologia e Conservação da Biodiversidade, Instituto de Biociências, Universidade Federal \\ de Mato Grosso. Avenida Fernando Corrêa da Costa 2367, 78060-900 Cuiabá, MT, Brazil. \\ 2 Corresponding author. Travessa Dom Pedro II 587, Auxiliadora, 69280-000 Manicoré, AM, Brazil. \\ E-mail: cleitonsignor@yahoo.com.br
}

\begin{abstract}
In this contribution we characterize the spatial diversity of bird populations in a heterogeneous landscape with respect to vegetation in the northern Pantanal region of Brazil. The method of additive partitioning of species diversity $(\gamma=\alpha+\beta)$ was used. Samples were collected in a grid with 30 sampling plots within a $25 \mathrm{~km}^{2}$ area $(5 \times 5 \mathrm{~km})$. A total of 163 bird species were found, comprising 114 resident species and 49 regional migrants. Most species were restricted spatially, with $58 \%$ found in a maximum of five sampling plots, while $15 \%$ were found in only one plot. The beta diversity comprised $77 \%$ of total diversity and was lower for residents than for regional migrants $(66 \%$ and $88 \%$, respectively). This suggests greater spatial heterogeneity in diversity patterns for regional migrants. Seasonal availability of resources caused by changing water levels as well as anthropogenic influences may also play a role in species diversity patterns by influencing species composition across sampling plots. High beta diversity and species-specific habitat occupancy suggest that conservation and management strategies should be implemented at a regional spatial scale and focus on the conservation of this environmental mosaic.
\end{abstract}

KEY WORDS. Additive diversity; beta diversity; flood plains; regional migration.

Spatial patterns of species diversity are the result of distinct environmental processes at different spatial scales such as topography, climate heterogeneity and differences in vegetation (Seoane et al. 2004, Van Rensburg et al. 2004, Cleary et al. 2005, Coreau \& Martin 2007, Veech \& Crist 2007). In general, habitat heterogeneity is positively correlated with species diversity (see review by Tews et al. 2004), being one of the most important factors to consider while examining species diversity patterns at different spatial scales (ATAURI \& LUCIO 2001, Seonne et al. 2004, Cleary et al. 2005).

The ecological consequences of habitat heterogeneity may vary considerably for different species, depending on how vegetation patterns are recognized (Tews et al. 2004, COREAU \& MARTIN 2007). This, in turn, may lead to variations in the patterns of land usage and occupancy of a species (WIENS 1989, Coreau \& Martin 2007). Spatial diversity patterns are fundamentally important for the design of conservation and management strategies (KATTAN et al. 2006). These patterns have proved useful in describing differences in spatial or temporal species richness and diversity, since they obviate the need to examine each of the several processes that may determine these differences (GERING et al. 2003).

Alpha $(\alpha)$, beta $(\beta)$ and gamma $(\gamma)$ diversities are all used to describe species diversity patterns (LoREAU 2000, Gering \& Crist 2002, Gering et al. 2003, Crist \& Veech 2006, Kattan et al.
2006, Veech \& CRIST 2007). Alpha diversity is defined as the diversity measured within a sample or community, whereas $\gamma$ refers to the regional diversity. Beta diversity quantifies the differences in species diversity across locations and provides a simple characterization of heterogeneity in a region. For this reason, it is used to plan conservation strategies and circumscribe protection areas (GERING et al. 2003, KatTAn et al. 2006). Beta diversity, or between-habitat diversity, seems to reflect the effects of landscape heterogeneity, such as that resulting from variations in climate or habitat (MACNALLY et al. 2004, ERÖs 2007, Veech \& CRist 2007).

The Pantanal, in central South America, is the world's largest seasonally flooded region. There, flood cycles vary in intensity among years, and often result in long periods of either severe drought or heavy floods (HeCKMAN 1999, NunEs DA CUNHA \& JUNK 2004). The result of this variable water regimen is a seasonal variation in resource availability, which in turn leads to different patterns of usage and occupancy of Pantanal habitats by resident and regional migrant birds (FIgUeIRA et al. 2006).

The Pantanal landscape has a wide variety of vegetation types that form mosaics of different habitats (Prance \& Shaller 1982, SiLva et al. 2000, CunHa et al. 2002). It also harbors the greatest bird species richness among similar flood plains, featuring 463 species, of which at least 133 have some migratory behavior (Tubelis \& Tomas 2003, Nunes \& TOMAs 2004). 
Bird seasonal migration patterns associated with flood cycles are among the most interesting phenomena observed in the Pantanal. Understanding how species with different movement patterns use habitats is extremely important for the planning of conservation strategies. Therefore, we developed this study to quantify the $\alpha$ and $\beta$ diversity of both resident and regionally migrating species inhabiting a heterogeneous vegetation landscape, in the northern Pantanal. Our aim was to examine how migrant and non-migrant bird species varied spatially in their use of habitat mosaics.

\section{MATERIAL AND METHODS}

The study area is located in Pirizal $\left(16^{\circ} 15^{\prime} \mathrm{S}, 56^{\circ} 22^{\prime} \mathrm{W}\right)$, in the municipality of Nossa Senhora do Livramento, state of Mato Grosso, Brazil (Fig. 1). This region is part of the Poconé subregion of the northern Pantanal (ADÁmoli 1982). Here, the dry season lasts from May to September, and the rainy season from October to April. Annual rainfall averages 1,400 mm. Maximum and minimum monthly rainfalls are in January and July, respectively (NuNES DA CUNHA \& JUNK 2004).

Similar to other areas of the Pantanal, a variety of habitat types is found in Pirizal, and, depending on topography, vegetation may change within very short distances (NUNES DA CunHa et al. 2006).

Samples were collected in a mosaic of five different vegetation types (Appendix 1 and Figs 2-7) in the seasonally flooded savannah. The study area includes three forest types, savannah and pasture, as described below:

Landis (LAN) ( $\mathrm{n}=5$ sampling plots) are continuous and sinuous geomorphologic depressions located in negative relief, 8-15 m in depth (Nunes da CunHa \& Junk 2009). They function as a drainage line during flood periods and are not flooded during the dry season. Landis are always close to "cambarazais", "cordilheiras" and "murunduns" (savanna park). The following species are characteristic of Landi forests: Licania parviflora (Chrysobalanaceae), Alchornea discolor (Euphorbiaceae) and Calophyllum brasiliensis (Guttiferae) (NuNES DA CUNHA et al. 2007) (Figs 2-3).

Cordilheiras (COR) $(n=3)$ are deciduous or semi-deciduous forests in which the ground is densely covered by bromeliads (Bromelea balansae). These bromeliads only occur in areas that are never flooded (NunEs DA CUNHA et al. 2006). Cordilheiras also harbor a dense undergrowth of up to $2 \mathrm{~m}$, and a 5-6-m canopy of Petiveria tetrandra (Phytolaccaceae) and Adelia membranifolia (Euphorbiaceae). These forests are continuous, long, winding strips of vegetation (Fig. 4) and have dense composite trees with a 8-20 $\mathrm{m}$ tall (SILVA et al. 2000).

Campos de Murundus (Murundus fields, MUR, $\mathrm{n}=14$ ) are seasonally flooded savannah fields with a small, round canopy (small "islands" that are never flooded, called murundus, with cover an area between 1 and $15 \mathrm{~m}^{2}$ ) in grassy flood plains (NunEs DA CUNHA et al. 2006, 2007). The upper stra-

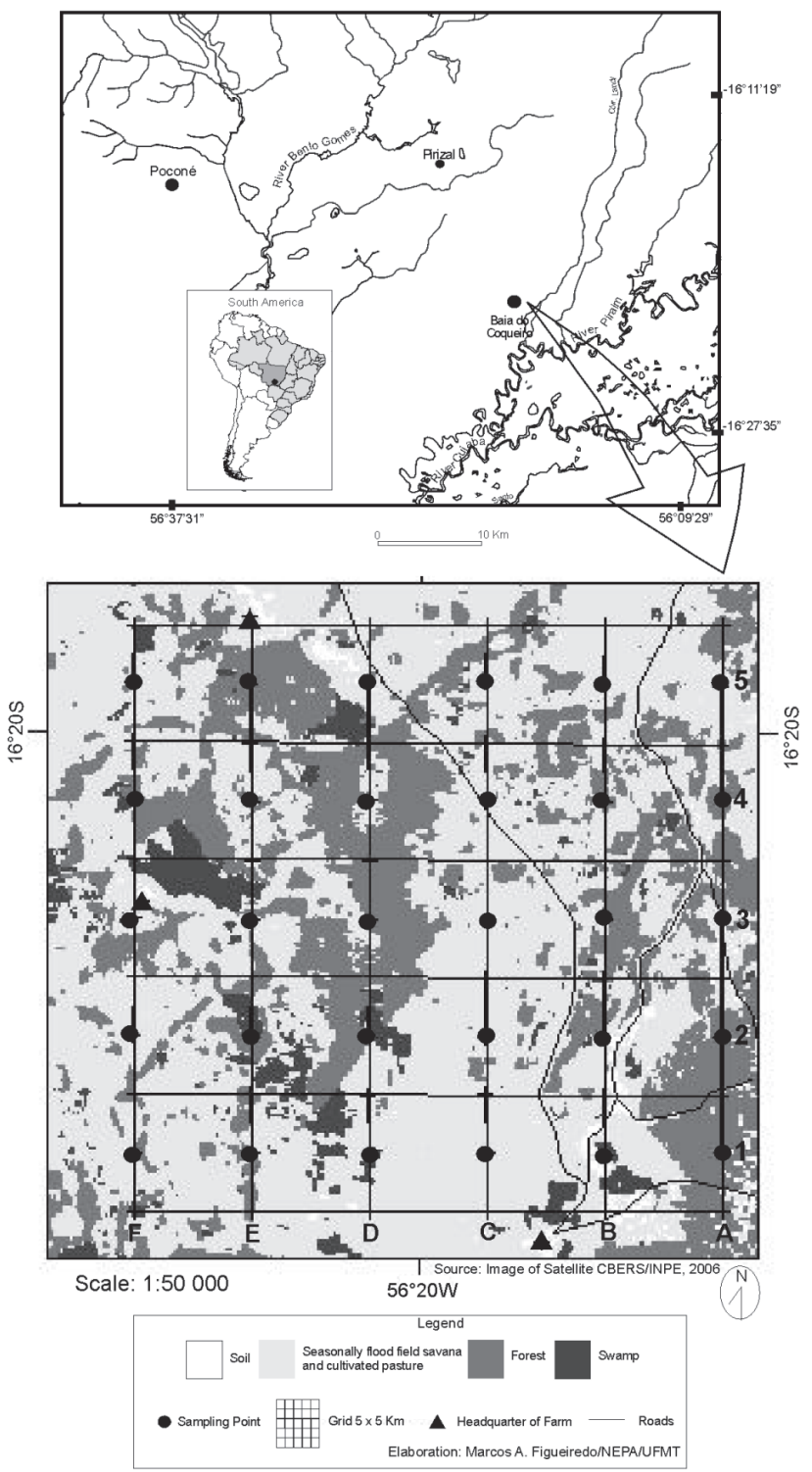

Figure 1. Map of the study area located in the Pantanal, near Poconé, and map of the sampling grid showing the 30 sampling plots distributed in different habitats.

tum is composed of shrubs and trees from 0.8 to $10 \mathrm{~m}$ high (Silva et al. 2000). The tree Curatella americana (Dilleniaceae) is locally abundant (Fig. 5).

Campos Limpos $(n=1)$ are sometimes flooded open fields with few trees and shrubs. Two additional sampling plots were edges of open and dense savannah (Fig. 6).

Pasto Cultivado (Cultivated Pasture, CUL, $\mathrm{n}=5$ ) are pastures for cattle, with exotic grasses (predominantly Brachiaria humidicola) and occasionally a few trees and shrubs (Fig. 7). 

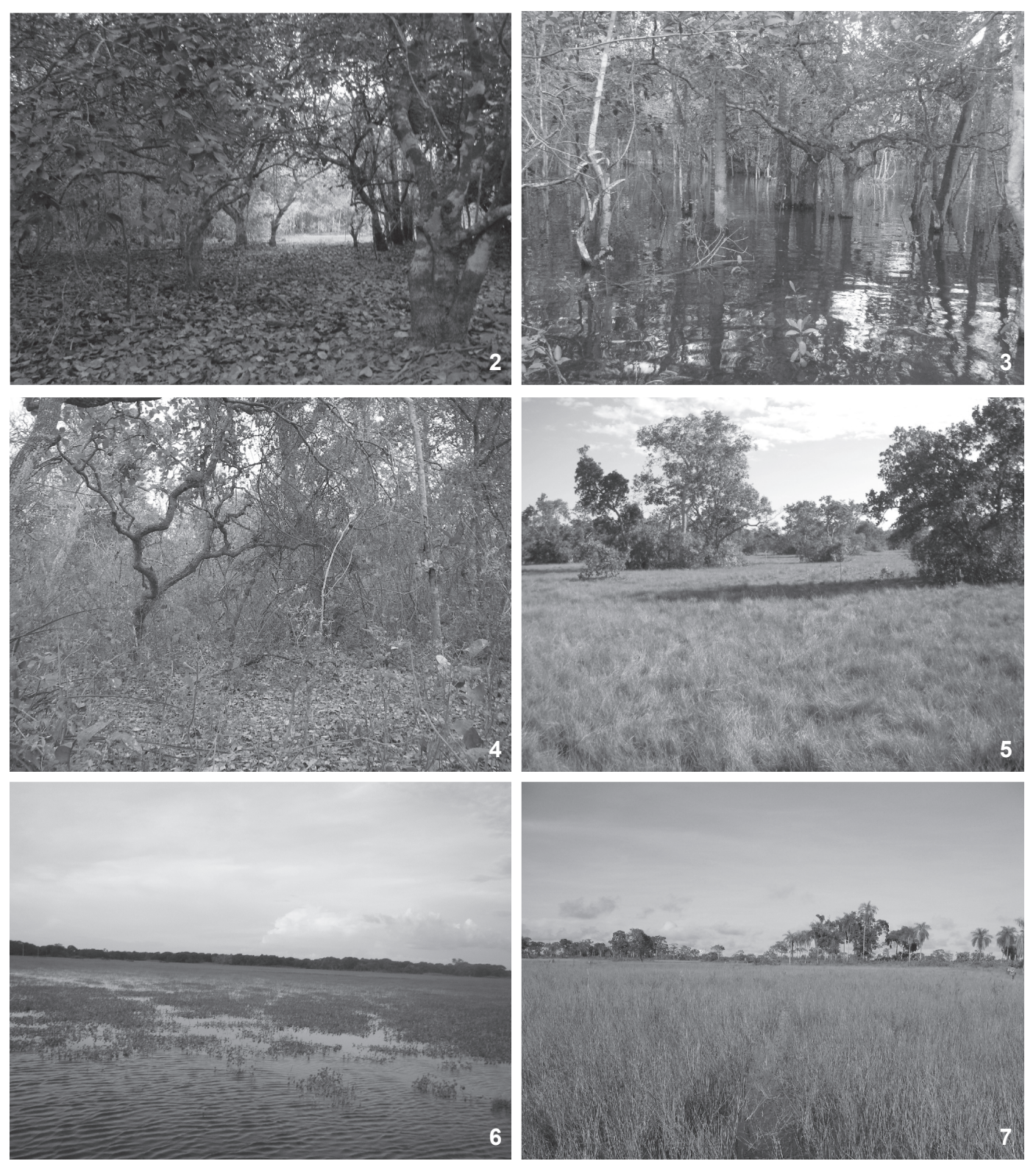

Figures 2-7. The five types of vegetation found in the study area are Landis, during the dry season (2) and flooded (3), Cordilheiras (4), Murundus fields (5), Campos Limpos (6) e Cultivated Pasture (7). Photos: Izaias Fernandes (2, 3 and 5-7) and Mônica Aragona (4).

Samples were collected in 30 sampling plots in a $5 \mathrm{x} 5 \mathrm{~km}$ grid (Fig. 1). The grid was formed by a system of six, $5 \mathrm{~km}$ long trailscovering a total area of $25 \mathrm{~km}^{2}$. A sampling plot was established every $1 \mathrm{~km}$ on the trails in the east-west direction. The $250 \mathrm{~m}$ long sampling plots were demarcated in order to follow the contour in linear sections 10 to $10 \mathrm{~m}$. The 30 sampling plots did not have a definite shape, for each sampling plot is the same corner of the field level and aim to minimize the variation of topography within each plot (MAGNUSson et al. 2005).
Birds were sampled during three sampling periods: August and September 2006 (dry weather, no rainfall, reproduction period of most bird species), February and March 2007 (floods), and May and June 2007 (runoff, with low rainfalls and some cold spells). Each sampling plot was surveyed once in each period. During sampling, birds were captured with mist nets or counted by sight and auditory recognition.

Birds were captured using 25 mist nets (36-mm mesh), $10 \mathrm{~m}$ long, $2.75 \mathrm{~m}$ in height, along each sampling plot. Nets 
were in a line along the sampling plot, and just above the ground or water level to avoid drowning during high water. Nets were opened from 6:00 to 10:00 a.m., for a total of 9,000 $\mathrm{h} /$ net $(100 \mathrm{~h} /$ net for each sampling plot in each collection season).

Birds were counted by sight or sound at three points counts, for $10 \mathrm{~min}$ each, along each sampling plot. During counting we strived to keep a maximum of $30 \mathrm{~m}$ between the observer and the subjects. Birds that flew over the canopy were ignored. Points were separated by $125 \mathrm{~m}$ and sampled in the same order, after the sunrise. Birds were counted in a total of 2,700 min (30 min in each sampling plot, in each collection season). When an unknown call or song was heard, we recorded the vocalization for later identification from a sounds library. One observer (C.A.S), trained on the methodology and familiarized with bird sounds conducted all sampling.

Estimates of species richness were calculated with the Jackknife 1 estimator by the program EstimateS 6.0 (Colwell 2005). Species richness estimates were compared with the observed total species richness in the study. In order to compare the relative contribution of the $\alpha$ and $\beta$ components of diversity with species diversity patterns, we compared the observed species richness with the respective richness estimate obtained using the Jackknife 1 estimator, for each sampling plot.

Nocturnal birds and some large bird species were excluded from the analysis because mist-nets may not be the appropriate sampling method for these species. The status of migration was defined based on the study of João B. Pinho (unpubl. data). Resident species were defined as those captured during $\geqslant 10$ months per year and regional migrants were those in the area for three to nine months. Vagrants (only seen in $\leqslant 2$ months) were excluded from the analysis. We consider those species as seasonal residents who were not registered in the grid of study in a least one of the three sampling stations. We compared patterns of spatial occupation ( $\alpha$ and $\beta$ components) among sampling plots (beta diversity) between residents and migrants using the Kolmogorov-Smirnov test, and among habitat types using the chi-square test. We used the chi-square test for habitats because there are few categories of habitats. Three plots were excluded from the analysis once habitat type was not defined.

We tested for a correlation between the relative abundance of each species and the number of sampling plots where each was recorded. Relative abundance is calculated by dividing the total number of individuals of a given species by the total number of individuals of all species. This correlation was used as a tool to check whether the patterns of diversity of resident species and migrants vary according to the relative abundance of both.

Regional diversity ( $\gamma$, species richness) was partitioned as $\alpha$ and $\beta$ diversities and expressed as $\gamma=\alpha+\beta$. Both $\alpha$ and $\beta$ diversities are expressed as means (LANDE 1996, VеECH et al. 2002). Here, $\alpha$ diversity is the mean number of species recorded in the
30 sampling plots, whereas $\beta$ represents the mean number of species recorded between sampling plots. Alfa and $\beta$ diversity, and expected species diversity based on the random occurrence of individuals in samples were estimated using the unrestricted individual-based randomization option with the program PARTITION (VEECH \& CRIST 2006). This test generates a significance value (p) that serves to show if alpha and beta diversity values found are significantly different from those expected by random occurrence. Our null hypothesis is that species are widely distributed on the sampling grid, and therefore we should expect a low beta diversity value.

Since the definition of $\beta$ diversity does not explicitly acknowledge the differences in samples or habitats (VеEсH et al. 2002), we estimated similarity between different sampling sites, using non-metric multidimensional scaling (NMDS), with the program Pcord (McCune \& MefFord 1999). Sampling plots were ranked in order of relative abundance and presence of species and Bray-Curtis similarity indexes (for abundance) and Sorensen similarity indexes (for presence) were calculated.

\section{RESULTS}

\section{General diversity patterns}

A total of 3,551 individuals (2,594 observed and 957 captured) in 132 genera and 163 species were recorded. Sixty four species were non-Passeriformes and the remainder (99) was Passeriformes (Appendix 1). The family with the most species was Tyrannidae (29 species), followed by Trochilidae (12), Columbidae (9) and Icteridae (9). Resident species comprised 114 species, of which 12 (found in only one season) and 30 (found in two seasons) were seasonal. Seventy two species were recorded in three seasons. In turn, regional migrants comprised 49 species, of which 22 were found in one season, 23 in two and four species were in all seasons. Overall, 77\% species were residents, $12 \%$ were seasonal residents and $10 \%$ were regional migrants.

Most species were spatially restricted: $58 \%$ were found in two to five sampling plots, and $15 \%$ were found in only one plot (Fig. 8 and Appendix 1). Residents and migrants had different patterns of spatial occupation on sampling plots (Kolmogorov-Smirnov Two Sample test: $p=0.004$ ). All residents recorded in one season only (12) were in one to four sampling plots, except for the toco toucan, Ramphastos toco Statius Muller, 1776, which was found in twelve sampling plots. Among the residents recorded in two seasons, $73 \%$ were noted in 1-5 sampling plots. Of the 72 residents in the three collecting seasons, 34 were noted at $\geqslant 10$ sampling plots, with 23 in $\geqslant 15$ or more sampling plots. Among the residents with the greatest spatial occupancy were the narrow-billed woodcreeper, Lepidocolaptes angustirostris (Vieillot, 1818); the great kiskadee, Pitangus sulphuratus (Linnaeus, 1766); the glittering throated emerald, Amazilia fimbriata (Gmelin, 1788); and the shortcrested flycatcher, Myiarchus ferox (Gmelin, 1789). 


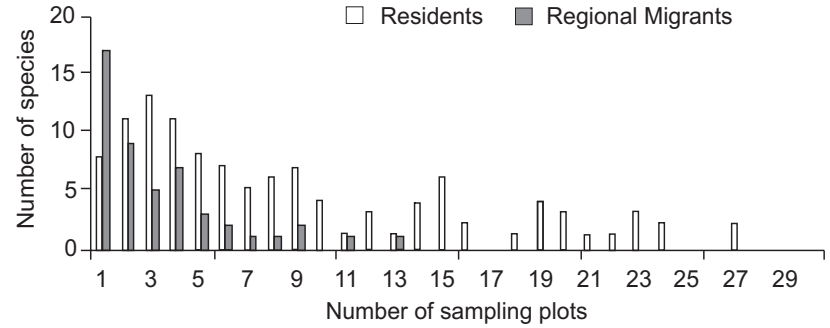

Figure 8. Number of sampling plots occupied by resident and regional migrant species near Poconé. Resident species were found in a significantly greater number of sampling plots than regional migrants (Kolmogorov-Smirnov test, $\mathrm{p}=0.004$ ).

As for the regional migrants, $86 \%$ were at a maximum of five sampling plots (Fig. 8). Relative abundance was positively correlated with the number of sampling plots at which the resident $(\mathrm{r}=0.794, \mathrm{p}<0.001)$ and regional migrants $(\mathrm{r}=0.54, \mathrm{p}=$ $0)$ species were encountered. Residents and migrants had different patterns of spatial occupation on habitat types $\left(\chi^{2}: 889.1\right.$; df: $4 \mathrm{p} \leqslant 0.0001$, Fig. 9).

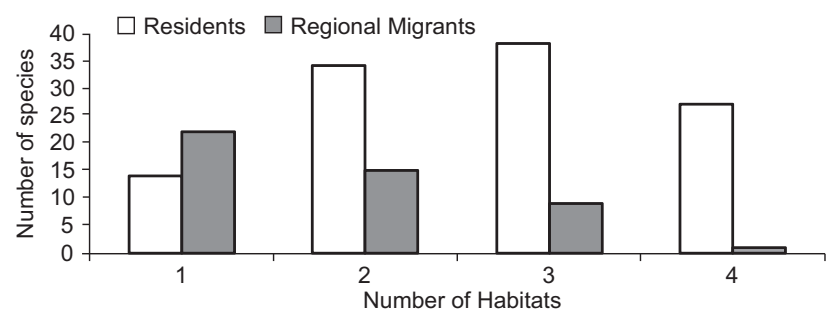

Figure 9. Number of habitats used by resident and regional migrant species near Poconé, MT, Brazil. Resident species were found in a significantly greater number of habitats than regional migrants $\left(\chi^{2}: 889.1\right.$, df: $\left.4, p \leqslant 0.0001\right)$.

The average species richness per habitat type was 41 species for Landis ( $n=5), 38.1$ for Murundus fields ( $n=14), 34.3$ for the Cordilheiras $(\mathrm{n}=3)$ and 33.8 for Cultivated Pasture $(\mathrm{n}=$ 5) (see Appendix 1).

\section{Species richness estimates}

The number of observed species (163) represented 89\% of the number expected to be found in our study (184 species, according to Jackknife species richness estimator). On average, there were 38 species $(\mathrm{SD}=9.12)$ at each sampling plot.

\section{Additive partitioning of species diversity}

The beta diversity accounted for $77 \%$ of the total species diversity (gama diversity) and was always greater than a randomly expected value $(\mathrm{p}<0.0001)$. The alfa diversity was $23 \%$ of the total diversity and was always lower than that expected $(\mathrm{p}<0.0001)$. The beta was lower for residents $(\beta=66 \%$ of total diversity) as compared with regional migrants ( $\beta=87 \%$ of total diversity). This suggests greater spatial heterogeneity in diversity patterns for regional migrants.

\section{Ordination}

NMDS explained $81.4 \%$ of the variation in bird species presence (Fig. 10) and $86.1 \%$ of the variation in species abundance (Fig. 11). The 30 sampling plots had marked variation in species richness and composition (Appendix 1). Sampling plots were grouped by habitats using both presence and abundance, with Murundus fields and two Landis (seasonably flooded forests) near water (Figs 10 and 11). Cultivated Pasture was also different from the rest and two of those sampling plot had the lowest species richness.

\section{DISCUSSION}

The comparison between the observed and the estimated species richness, for the entire study area $(\gamma)$ and for every sampling plot $(\alpha)$, as well as the small variation in estimated species richness across all sampling plots, reveals that the sampling approach was satisfactory, and suggests that the diversity patterns observed are consistent.

\section{Use of habitats and $\beta$ diversity}

The high $\beta$ diversity value obtained reveals considerable spatial heterogeneity of bird diversity patterns. The effect of habitat heterogeneity on bird spatial diversity patterns is supported by the fact that some species occupy certain habitats in particular. Among these species are some residents, such as the Mato Grosso ant bird, Cercomacra melanaria (Menetries, 1835); the band tailed ant bird, Hypocnemoides maculicauda (Pelzeln, 1868); and the Cerrado endemic helmeted manakin, Antilophia galeata (Lichtenstein, 1823), which were restricted to two Landis areas (seasonally flooded forests-LAN), near one permanent water course. In the Pantanal, C. melanaria and H. maculicauda had been found in association with wet forests occurring near water courses (PINHo et al. 2006). The presence of these and other species in those two areas indicates that the suppression of forest habitats near water courses may be extremely deleterious to the bird fauna of the Pantanal, especially to $C$. melanaria, a species found almost exclusively in the biome (Sтот乙 et al. 1996). Other species such as the ruby topaz hummingbird, Chrysolampis mosquitus (Linnaeus, 1758), and the buffthroated woodcreeper, Xiphorhynchus guttatus (Lichtenstein, 1820), occur only in Cordilheiras (non-flooded forests-COR). These species are certainly not confined to the non-flooded areas. For instance, C. mosquitus was observed in the four forest types sampled by João B. Pinho (unpubl. data) in Pirizal. Nevertheless, these and other species are restricted to forest environments, demonstrating the importance of preserving these forests to maintain the bird fauna. A similar circumstance is observed in Murundu fields, the only habitat where species such as the white-throated kingbird, Tyrannus albogularis Burmeister, 1856; the Cerrado endemic species white rumped 


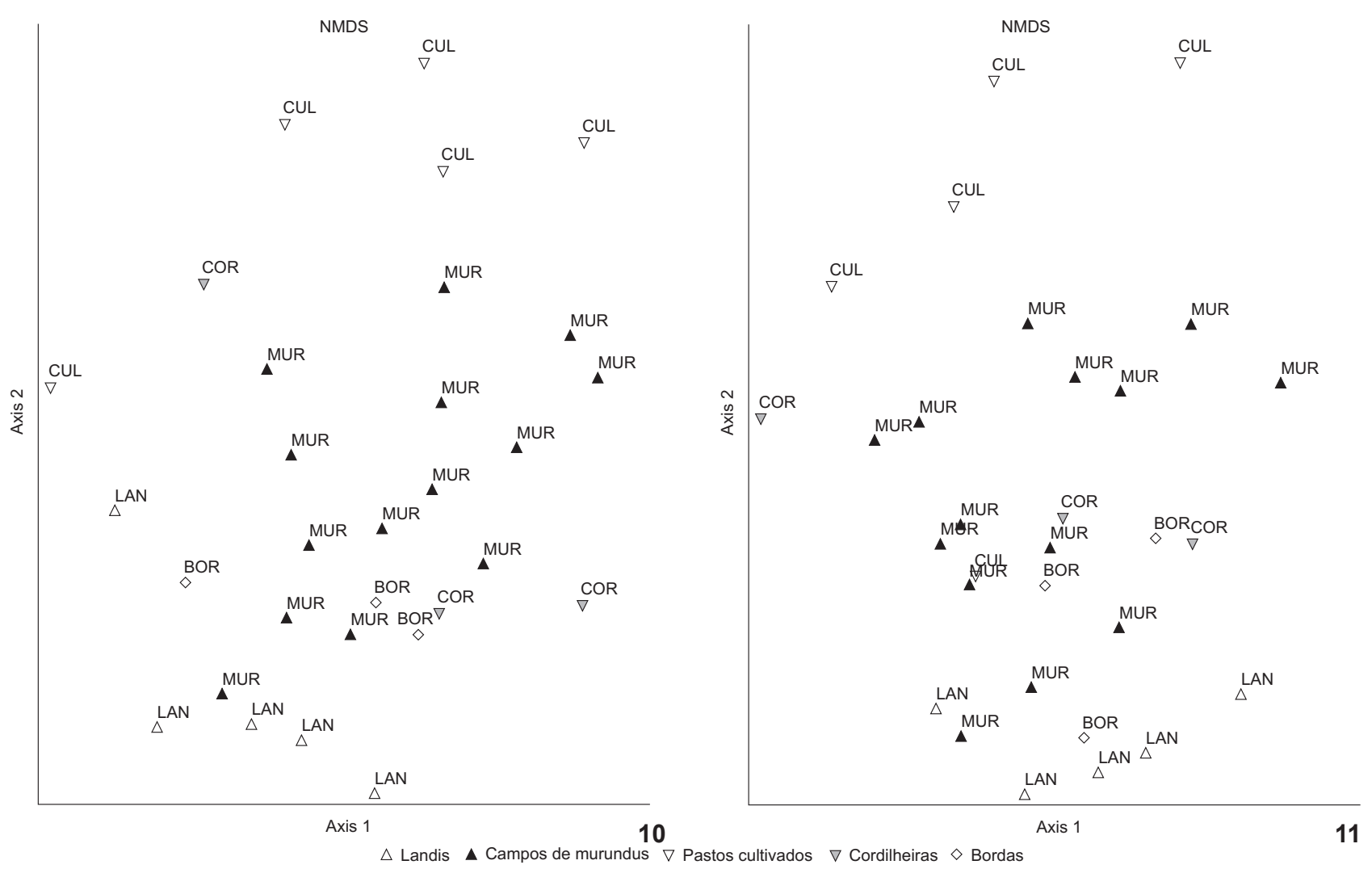

Figures 10-11. NMDS Ordination of the 30 sampling plots based on their bird species composition: (10) species presence or absence data; (11) relative abundance.

tanager, Cypsnagra hirundinacea (Lesson, 1831); and black throated saltador, Saltator atricollis Vieillot, 1817, were found.

Most species in the Pantanal seem to depend on multiple habitats to survive throughout the year, due to the seasonality of habitats and resources brought in by seasonal floods, as already suggested by Figueira et al. (2006). Reliance on multiple habitats is more intense among resident species, which have to find additional resources in different habitats during the year in order to deal with yearly oscillations in resource availability. In fact, residents occupy a larger number of sampling plots (greater $\alpha$ values) as compared with regional migrants, though $\beta$ diversity remained high. Therefore, even though residents tend to occupy several habitat types throughout the year (which would lower their respective $\beta$ diversity values), spatial occupancy in a given period was shown to be highly heterogeneous. This stresses the need for the conservation of multiple environments for the sake of maintaining species diversity in the Pantanal, throughout the year.

Among the residents, non-seasonal species, such as the white-wedged piculet, Picumnus albosquamatus Orbigny, 1840, were most widely distributed among sampling plots. On the other hand, most seasonal residents and regional migrants oc- cupied few sampling plots - e.g., the spot-backed puffbird, Nystalus maculatus (Gmelin, 1788), and the white-crested elaenia, Elaenia albiceps (Orbigny \& Lafresnaye, 1837). The strong correlation between abundance and occupation suggests that restricted occupation of regional migrants is due to the low abundance of these species. A study accessing four forest environments in the same area found that bird species that remain in the Pantanal during a greater number of seasons occupy a greater the number of different forest habitats (João B. Pinho, unpubl. data). Species abundance is greater where ecological conditions are more favorable (WIENs 1989), which suggests that residents have adapted to the seasonality of the Pantanal. However, they do not seem so rare to justify the low value of alpha diversity, and so it is not possible to rule out that this effect is due to preference for the use of certain habitats by these species.

Seasonal usage of habitats by seasonal residents and regional migrants also seems to reflect seasonality in resource availability. For instance, some aquatic or semi-aquatic seasonal residents, such as $H$. maculicauda and the yellow-chinned spinetail, Certhiaxis cinnamomea (Gmelin, 1788), were observed in the area only during flood periods, which coincide with the 
reproductive period of these species (C.A. Signor, pers. obs.). Several other species occupy different habitat types only in specific flood seasons, such as the frugivorous blue-crowned trogon, Trogon curucui Linnaeus, 1766, which occurred only in dry periods, in forests habitats. Therefore, the different specific resource requirements exhibited by some species, some of which are related to distinct flood periods, side by side with the temporal seasonality of the Pantanal, increased the spatial heterogeneity of bird diversity in the sampling grid. This was manifested as the greater $\beta$ and $\gamma$ diversity values measured. Therefore, changes in water flow and in the Pantanal hydrological regimes - caused chiefly by development projects implemented by the government, such as hydroelectric power dams and the transformation of natural Cerrado habitats adjacent to the Pantanal into agricultural zones - may alter the seasonal dynamic of habitat occupancy by birds. In turn, these alterations may lead to the local extinction of some representatives of native birds that depend on this seasonality, apart from the related environmental and economic losses (HARRIs et al. 2005, Galdino \& VieIra 2006), which are a burden to the government and to the society.

Apart from the different resource requirements, vagility levels determine how different species or groups of species sense and use a mosaic of habitats (LAW \& DickMAn 1998, BenNet et al. $2004,2006)$. In a survey of several mosaics of $25-\mathrm{km}^{2}$ forest fragments in England, migrant bird richness was strongly influenced by ecological factors at the regional scale, especially habitat patterns and availability of habitats, whereas resident species richness was more intensely affected by local ecological aspects (BENnet et al. 2004). These considerations suggest that the starting point for the establishment of migrants may be the availability of habitats and resources at the regional level. Therefore, lower richness, abundance and spatial occupancy of regional migrants may be the consequences of the response of these species to the availability of resources and habitats at larger spatial scales. The same may happen with seasonal residents, which were also uncommon and in few places. Thus, to conserve bird diversity and the seasonal dynamic of occupancy by different species in the Pantanal, conservation strategies should be planned at regional levels.

The uncommonness of regional migrant birds may also be due to the greater energetic requirements of these species with respect to migration, which would compel them to be more habitat-selective. The influence of habitat selection on $\beta$ diversity, as seen in the additive model, was also seen in moths and host plants. Here, generalist moth species had lower $\beta$ diversities in comparison with specialists at several spatial scales (Summerville et al. 2006).

Finally, part of the notion that the difference in the $\alpha$ and $\beta$ components of diversity between resident and regional migrants may be due to a sampling bias cannot be entirely ruled out, since spatial patterns for regional migrants are more susceptible to errors, due to their shorter stay in the study area.

\section{Anthropogenic influence on beta diversity}

The marked differences in species composition between the sampling plots in Cultivated Pasture suggest that at least part of the $\beta$ diversity may be explained byhuman disturbance (Figs 10 and 11). In Cultivated Pasture, exotic grasses are dominant, and only occasionally trees and shrubs are also present. Apparently, the presence of scattered shrubs and trees was the main factor determining the presence of many species in the pasture areas. In the Cerrado biome, the number of species in pastures with shrubs was $120 \%$ greater than in those without shrubs (Tubelis \& CaVAlCanTI 2000). This difference is due to the fact that birds which depend on shrubs and canopy layers are absent from the Cultivated Pasture. Isolated trees, typical of natural pastures, favor animal diversity (Tews et al. 2004) by providing perches for birds and frugivorous bats (GUEvara et al. 1986). A reduction in the number of trees and shrubs in Pantanal pastures may lead to a loss of resources deemed important for the reproduction, feeding and sheltering of several species. Also, such reduction may influence movement patterns of species that use trees and shrubs as ecological facilitators when traveling over different areas and habitats in the Pantanal. During floods, fields lacking trees and shrubs become unavailable to aquatic and semi-aquatic birds. This was particularly clear at one sampling plot in a pasture area with almost no trees and shrubs, in which no birds were captured in the rainy season and during runoff.

In pastures, how dominance of exotic grasses influences birds has not been investigated. We found that birds typically associated with fields, such as the black throated saltador, $S$. atricollis and the rusty-collared seedeater, Sporophila collaris (Boddaert, 1783), are present in areas with exotic grasses. More specific studies are needed to shed more light on how exotic grasses influence native birds in the Pantanal.

\section{Final considerations}

The model of additive partitioning of species diversity appears to be an excellent tool to evaluate regional diversity using species diversity patterns. Understanding these patterns will help in decision-making for conservation and management of natural landscapes. In the Pantanal, high $\beta$ diversity and locally restricted occupation suggest that conservation and management strategies should be implemented at regional scales and focus on the conservation of this mosaic of environments. Due to the urgent need for national conservation and research priorities for Brazilian birds (MARINI \& GARCIA 2005), we believe that investing in the study of diversity patterns may be an efficient pathway to understanding regional heterogeneity. With that understanding, it will be easier to design effective conservation strategies. In the Pantanal, migratory movements associated with environmental seasonality lead to seasonal variations in species richness and composition. Since species composition is the most important factor determining community patterns (WIENs 1989), further research should be conducted to investigate how these seasonal variations may 
affect the patterns of spatial use of habitat mosaics during the different seasons, in the different sub-regions of the Pantanal, and at distinct spatial scales.

\section{ACKNOWLEDGMENTS}

This study was financed by Centro de Pesquisa do Pantanal (CPP/BIOPAN), Instituto Nacional de Ciências e Tecnologia em Áreas Úmidas (INAU), Pesquisas Ecológicas de Longa Duração (PELD), and Ministério de Ciência e Tecnologia (MCT). We are grateful to the Coordenadoria de Aperfeiçoamento de Pessoal de Nivel Superior (CAPES) for the fellowship offered to C.A.S, and to the Programa de Pós-graduação em Ecologia e Conservação da Biodiversidade, UFMT. We are also indebted to C. Strussman, J.M. Penha, R.M. Silveira, J.E. Figueira, J. Veech and to the anonymous reviewers for the critical reading of this manuscript. Our gratitude goes also to the people who helped in the field work, especially M.M. Evangelista, A. Iá, and M.A. Figueiredo for the production of maps. James J. Roper reviewed and provided constructive suggestions for the improvement of the manuscript and the English.

\section{LITERATURE CITED}

ADÁmoli, J. 1982. O Pantanal e suas relações fitogeográficas com os Cerrados. Discussão sobre o conceito de "Complexo do Pantanal", p. 109-119. In: Anais do XXXII Congresso Nacional de Botânica. Teresina, Sociedade Brasileira de Botânica.

Atauri, J.A. \& J.V. Lucio. 2001. The role of landscape structure in species richness distribution of birds, amphibians, reptiles and lepidopterans in Mediterranean landscapes. Landscape Ecology 16: 147-159.

Bennett, A.F.; S.A. Hinsley; P.E. Bellamy; R.D. Swetnam \& R. MaC NALlY. 2004. Do regional gradients in land-use influence richness, composition and turnover of bird assemblages in small woods? Biological Conservation 119: 191-206.

Bennett, A.F; J.Q. Radford \& A. Haslem. 2006. Properties of land mosaics: Implications for nature conservation in agricultural environments. Biological Conservation 133: 250-264.

Cleary, F.R.D.; M.J. Genner; T.J.B. Boyle; T. Setyawati; C.D. Angraeti \& S.B.J. Menken. 2005. Associations of bird species richness and community composition with local and landscape-scale environmental factors in Borneo. Landscape Ecology 20: 989-1001.

Colwell, R.K. 2005. Estimates: statistical estimation of species richness and shared species from samples. Version 6.0 persistent. Available online at: http:/purl.oclc.org/estimates [Accessed: X/2007].

Coreau, A. \& J.-L. Martin. 2007. Multi-scale study of bird species distribution and of their response to vegetation change: a Mediterranean example. Landscape Ecology 22: 747-764.

Crist, T.O. \& J.A. Veech. 2006. Additive partitioning of rarefaction curves and species-area relationships: unifying $\alpha, \beta$ and $\gamma$ - diversity with sample size and habitat area. Ecology Letters 9: 923-932.

Cunha, C.N.; W.J. Junk \& E.A. Silveira. 2002. A importância da diversidade da paisagem e diversidade arbórea para a consrvação do Pantanal, p. 71-76. In: E.L. AraúJo; A.N. MourA; E.V.S.B. Sampaio; L.M.S. Gestinari \& J.M.T. Carneiro (Eds). Biodiversidade, conservação e uso sustentado da flora no Brasil. Recife, Imprensa universitária, Universidade federal de Pernambuco.

ERös, T. 2007. Partitioning the diversity the riverine fish: the role of habitat types and non-native species. Freshwater Biology 52: 1400-1415.

Figueira, J.E.C.; R. Cintra, L.R. Viana \& A.C. Yamashita. 2006. Spatial and temporal patterns of bird species diversity in the Pantanal of Mato Grosso, Brazil: Implications for Conservation. Brasilian Journal of Biology 66 (2A): 393-404.

Galdino, S. \& L.M. Vieira. 2006. A Bacia do Rio Taquari e seus problemas ambientais e socioeconômicos, p. 29-43. In: S. Galdino; L.M. Vieira \& L.A. Pellegrin (Eds). Impactos ambientais e socioeconômicos na Bacia do Rio Taquari. Corumbá, Embrapa Pantanal.

Gering, J.C. \& T.O. Crist. 2002. The alpha-beta-regional relationship: providing new insights into local-regional patterns of species richness and scale dependence of diversity components. Ecology Letters 5: 433-444.

Gering, J.C; T.O. Crist \& J.A. Veech. 2003. Additive Partitioning of Species Diversity across Multiple Spatial Scales: Implications for Regional Conservation of Biodiversity. Conservation Biology 17 (2): 488-499.

Guevara, S.; S. Purata \& E. Van Der Maarel. 1986. The role of remnant trees in tropical secondary succession. Vegetatio 66: 77-84.

Harris, M. B.; W. Tomas; G. MourÃo; C.J. Da Silva; E. Guimarães; F. SONODA \& E. FACHIM. 2005. Safeguarding the Pantanal Wetlands: Threats and Conservation Initiatives. Conservation Biology 19 (3): 714-720.

Heckman, C.W. 1999. Geographical and climatic factors as determinants of the biotic differences between the northern and southern parts of the Pantanal Mato-grossense, p. 167175. In: Anais do II Simpósio sobre Recursos Naturais e Sócio-Econômicos do Pantanal: Manejo e Conservação. Corumbá, Embrapa Pantanal.

Kattan, G.H.; P. Franco; C.A. Saavedra-Rodríguez; C. Valderrama; V. Rojas; D. Osório \& J. Martinez. 2006. Spatial components of bird diversity in the Andes of Colombia: Implications for designing a regional reserve system. Conservation Biology 20 (4): 1203-1211. DOI: 10.1111/j.1523-1739.2006.00402.x

LANDE, R. 1996. Statistics and partitioning of species diversity and similarity among multiple communities. Oikos 76: 5-13.

LaW, B.S. \& C.R. Dickman. 1988. The use of habitats mosaics by terrestrial vertebrates fauna: Implications for conservation and management. Biodiversity and Conservation 7: 323333. 
LOREAU, M. 2000. Are communities satured? On the relationship and $\alpha, \beta$ and $\gamma$ diversity. Ecology Letters 3: 73-76.

MacNally, R.; E. Fleishman; L.P. Bulluck \& C.J. Betrus. 2004. Comparative influence of spatial scale on beta diversity within regional assemblages of birds and butterflies. Journal of Biogeography 31: 917-929.

Magnusson, W.E.; A.P. Lima; R.C. LUIZÃo; F. LuizÃo, F.R.C. Costa; C.V. CASTILLo \& V.F. KinUPP. 2005. RAPELD: uma modificação do método de Gentry para inventários de biodiversidade em sítios para pesquisa ecológica de longa duração. Biota Neotropica 5 (2): 1-6. Available online at: http:// www.biotaneotropica.org.br/v5n2/pt/abstract?point-ofview+bn01005022005 [Accessed: 13/X/2011]

MARINI, M.Â. \& F.I. GarCIA 2005. Bird conservation in Brazil. Conservation Biology 19 (3): 665-671.

Mccune, B. \& M.J. Mefford. 1999. PC-ORD: multivariate analysis of ecological data. Gleneden Beach, MjM Software Design, version 4.

Nunes, A.P.\& W.M. Tomas. 2004. Aves migratórias ocorrentes no Pantanal: Caracterização e Conservação. Corumbá, Embrapa Pantanal, Série Documentos 62, p. 1-25.

Nunes dA CunHa, C. \& W.J. Junk. 2004. Year-to-year changes in water level drive the invasion of Vochysia divergens in Pantanal grasslands. Applied Vegetation Science 7: 103-110.

Nunes da Cunha, C. \& W.J. Junk. 2009. Landscape units of the Pantanal: structure, function, and human use, p. 127-141. In: W.J. Junk, C.J. da Silva; C. Nenes da Cunha \& K.M. Wantzen (Eds). The Pantanal: Ecology, biodiversity and sustainable manageament of a large neotropical seasonal wetland. Sofia, Pensoft Publishers.

Nunes da Cunha, C.; P. Rawiel; K.M. Wantzen; W.J. Junk \& A. Lemes Do Prado. 2006. Mapping and characterization of vegetation units by means of Landsat imagery and management recommendations for the Pantanal of Mato Grosso (Brazil), north of Poconé. Amazoniana 19 (1/2): 1-32.

Nunes da Cunha, C.; W.J. Junk \& H.F. Leitão-Filho. 2007. Wood vegetation in the Pantanal of Mato Grosso, Brazil: a preliminary typology. Amazoniana 19 (3/4): 159-184.

Pinho, J.B.; L.E. Lopes; D.H. de Morais \& A.M. Fernandes. 2006. Life history of the Mato Grosso Antbird Cercomacra melanaria in the Brazilian Pantanal. Ibis 148: 321-329.

Prance, G.T. \& G.B. Shaller. 1982. Preliminary study of some vegetation types of Pantanal, Mato Grosso, Brazil. Brittonia 34: $228-251$.

Seoane, J.; J. Bustamante \& R. Díaz-Delgado. 2004. Competing roles for landscape, topography and climate in predictive models of bird distribution. Ecological Modelling 171: 209-222.

Silva, M.P.; R. Mauro; G. Mourão \& M. Coutinho. 2000. Distribuição e quantificação de classes de vegetação do Pantanal através de levantamento aéreo. Revista Brasileira de Botânica 23: 143-152.

Stotz, D.F.; J.W. Fitzpatrick; T. Parker III \& D.K. Moskovits. 1996. Neotropical Birds: Ecology and Conservation. Chicago, University of Chicago Press.

Summerville, K.S.; T.D. Wilson; J.A. Veech \& T.O. Crist. 2006. Do body size and diet breadth affect partitioning of species diversity? A test with forest Lepidoptera. Diversity and Distributions 12: 91-99.

Tews, J.; U. Brose; V. Grimm; K. Tielborger; M.C. Wichmann; M. SChWAger \& F. Jeltsch. 2004. Animal species diversity driven by habitat heterogeneity/diversity: the importance of keystone structures. Journal of Biogeography 31: 79-92.

Tubelis, D.P. \& R.B. Cavalcanti. 2000. A comparison of bird communities in natural and disturbed non-wetland open habitats in the Cerrado's central region, Brazil. Bird Conservation International 10: 331-350.

Tubelis, D.P. \& W.M. Tomas. 2003. Bird species of the Pantanal wetland, Brazil. Ararajuba 11 (1): 5-37.

Van Rensburg, B.J.; P. Kollef; K.J. Gaston \& S.L. Chown. 2004. Spatial congruence of ecological transition at the regional scale in South Africa. Journal of Biogeography 31: 843-854.

VEECH, J.A. \& T.O. CRIST. 2006. PARTITION: software for hierarchical additive partitioning of species-diversity. Version 2.0. Available online at: http://www.users.muohio.edu/cristto/ partition.htm [Accessed: 13/X/2011]

VeECH, J.A. \& T.O. CRIST. 2007. Habitat and climate heterogeneity maintain beta-diversity of birds among landscapes within ecoregions. Global ecology and Biogeography 16: 650-656.

Veech, J.A.; K.S. Summerville; T.O. Crist \& J.C. Gering. 2002. The additive partitioning of species diversity: recent revival of an old idea. Oikos 99: 3-9.

Wiens, J.A. 1989. The Ecology of Bird Communities: Foundations and patterns. Cambridge University Press, Cambridge.
Submitted: 23.XI.2010; Accepted: 30.VII.2011.

Editorial responsibility: Heraldo L. de Vasconcelos 
Appendix 1. List of the bird found during this study, and species abundances by habitat and counting method. Species status: Resident (R) and Regional migrants (M); Number of sampling plots ( $\mathrm{N}$ Splots) and number of habitats ( $\mathrm{N}$ habitats) occupied by each species. Seasons when seen: dry season (Dry), rainy season (Rai) and runoff (Run). Habitats: Landis (LAN, $n=5$ )-seasonally flooded forest); Cordilheiras (COR $(n=3)$-Dense-canopy savannah); Murundus fields (MUR, $n=14$ )-Seasonally flooded field savannah, of which three were invaded by the tree species cambará, Vochysia divergens Pohl. (Vochysiaceae); Cultivated Pasture (CUL, $\mathrm{n}=5$ )-Open pastures; Two borders between Cordilheiras and Murundu fields (Bord) and one border between Cordilheiras and open field (flood open field areas-Bord1).

\begin{tabular}{|c|c|c|c|c|c|c|c|c|c|c|c|c|c|}
\hline \multirow{2}{*}{ Taxon } & \multirow{2}{*}{ Status } & \multirow{2}{*}{$\begin{array}{c}\mathrm{N} \\
\text { Points }\end{array}$} & \multirow{2}{*}{$\begin{array}{c}\mathrm{N} \\
\text { Habitats }\end{array}$} & \multirow{2}{*}{ Abund } & \multirow{2}{*}{ Dry } & \multirow{2}{*}{ Rai } & \multirow{2}{*}{ Run } & \multicolumn{6}{|c|}{ Habitat } \\
\hline & & & & & & & & LAN & COR & MUR & CUL & BORD & BORD1 \\
\hline \multicolumn{14}{|l|}{ Tinamiformes } \\
\hline \multicolumn{14}{|l|}{ Tinamidae } \\
\hline Crypturellus undulatus (Temminck, 1815) & $\mathrm{R}$ & 7 & 2 & 9 & $x$ & $\mathrm{x}$ & $\mathrm{x}$ & 1 & 0 & 5 & 0 & 1 & 2 \\
\hline Rhynchotus rufescens (Temminck, 1815) & M & 6 & 1 & 7 & $\mathrm{x}$ & & $\mathrm{x}$ & 0 & 0 & 7 & 0 & 0 & 0 \\
\hline \multicolumn{14}{|l|}{ Falconiformes } \\
\hline \multicolumn{14}{|l|}{ Accipitridae } \\
\hline Rostrhamus sociabilis (Vieillot, 1817) & M & 3 & 1 & 3 & & $\mathrm{x}$ & & 0 & 0 & 3 & 0 & 0 & 0 \\
\hline Busarellus nigricollis (Latham, 1790) & $\mathrm{R}$ & 1 & 1 & 1 & & & $\mathrm{x}$ & 1 & 0 & 0 & 0 & 0 & 0 \\
\hline Rupornis magnirostris (Gmelin, 1788) & $\mathrm{R}$ & 14 & 3 & 19 & $x$ & $x$ & $x$ & 3 & 0 & 12 & 2 & 1 & 1 \\
\hline \multicolumn{14}{|l|}{ Falconidae } \\
\hline Caracara plancus (Miller, 1777) & M & 2 & 2 & 3 & $x$ & & & 0 & 0 & 2 & 1 & 0 & 0 \\
\hline Milvago chimachima (Vieillot, 1816) & $\mathrm{R}$ & 2 & 2 & 3 & $x$ & $x$ & & 0 & 0 & 1 & 2 & 0 & 0 \\
\hline Herpetotheres cachinnans (Linnaeus, 1758) & $\mathrm{R}$ & 2 & 2 & 2 & & $x$ & & 0 & 1 & 1 & 0 & 0 & 0 \\
\hline Falco rufigularis Daudin, 1800 & M & 1 & 1 & 1 & & $\mathrm{x}$ & & 0 & 0 & 0 & 1 & 0 & 0 \\
\hline \multicolumn{14}{|l|}{ Gruiformes } \\
\hline \multicolumn{14}{|l|}{ Rallidae } \\
\hline Aramides cajanea (Statius Muller, 1776) & $\mathrm{R}$ & 7 & 4 & 15 & $x$ & & $x$ & 1 & 1 & 4 & 7 & 2 & 0 \\
\hline Porphyrio flavirostris (Gmelin, 1789) & M & 4 & 1 & 9 & & $\mathrm{x}$ & & 0 & 0 & 0 & 7 & 0 & 2 \\
\hline \multicolumn{14}{|l|}{ Eurypygidae } \\
\hline Eurypyga helias (Pallas, 1781) & M & 1 & 1 & 1 & & & $\mathrm{x}$ & 0 & 0 & 0 & 1 & 0 & 0 \\
\hline \multicolumn{14}{|l|}{ Charadriiformes } \\
\hline \multicolumn{14}{|l|}{ Jacanidae } \\
\hline Jacana jacana (Linnaeus, 1766) & $\mathrm{R}$ & 3 & 2 & 9 & & $x$ & $x$ & 0 & 0 & 2 & 7 & 0 & 0 \\
\hline \multicolumn{14}{|l|}{ Columbiformes } \\
\hline \multicolumn{14}{|l|}{ Columbidae } \\
\hline Columbina minuta (Linnaeus, 1766) & M & 4 & 3 & 5 & $x$ & & $\mathrm{x}$ & 1 & 0 & 2 & 2 & 0 & 0 \\
\hline Columbina talpacoti (Temminck, 1811) & $\mathrm{R}$ & 17 & 3 & 86 & $x$ & $x$ & $x$ & 12 & 30 & 41 & 0 & 3 & 0 \\
\hline Columbina squammata (Lesson, 1831) & $\mathrm{R}$ & 6 & 2 & 15 & $x$ & $\mathrm{x}$ & $\mathrm{x}$ & 0 & 0 & 6 & 1 & 5 & 3 \\
\hline Columbina picui (Temminck, 1813) & $\mathrm{R}$ & 4 & 3 & 24 & $\mathrm{x}$ & & $\mathrm{x}$ & 0 & 18 & 1 & 5 & 0 & 0 \\
\hline Claravis pretiosa (Ferrari-Perez, 1886) & $\mathrm{R}$ & 4 & 2 & 7 & $\mathrm{x}$ & & $\mathrm{x}$ & 3 & 0 & 3 & 0 & 1 & 0 \\
\hline Uropelia campestris (Spix, 1825) & M & 4 & 3 & 12 & $x$ & $x$ & $x$ & 0 & 1 & 7 & 4 & 0 & 0 \\
\hline Patagioenas cayennensis (Bonnaterre, 1792) & $\mathrm{R}$ & 3 & 2 & 5 & $\mathrm{x}$ & $\mathrm{x}$ & & 0 & 0 & 2 & 3 & 0 & 0 \\
\hline Leptotila verreauxi Bonaparte, 1855 & $\mathrm{R}$ & 15 & 4 & 28 & $x$ & $x$ & $x$ & 3 & 4 & 7 & 8 & 4 & 2 \\
\hline Leptotila rufaxilla (Richard \& Bernard, 1792) & $\mathrm{R}$ & 2 & 2 & 2 & $\mathrm{x}$ & & $\mathrm{x}$ & 1 & 0 & 1 & 0 & 0 & 0 \\
\hline Psittaciformes & & & & & & & & & & & & & \\
\hline Psittacidae & & & & & & & & & & & & & \\
\hline Primolius auricollis (Cassin, 1853) & $\mathrm{R}$ & 4 & 2 & 9 & $x$ & & $x$ & 0 & 0 & 4 & 2 & 0 & 3 \\
\hline Aratinga leucophthalma (Statius Muller, 1776) & M & 1 & 1 & 6 & & $x$ & & 0 & 0 & 6 & 0 & 0 & 0 \\
\hline Aratinga aurea (Gmelin, 1788) & $\mathrm{R}$ & 3 & 2 & 6 & & $x$ & $\mathrm{x}$ & 0 & 0 & 2 & 4 & 0 & 0 \\
\hline Brotogeris chiriri (Vieillot, 1818) & $\mathrm{R}$ & 7 & 3 & 23 & $x$ & $x$ & $x$ & 0 & 11 & 5 & 7 & 0 & 0 \\
\hline Amazona aestiva (Linnaeus, 1758) & $\mathrm{R}$ & 15 & 4 & 50 & $\mathrm{x}$ & $\mathrm{x}$ & $\mathrm{x}$ & 11 & 11 & 16 & 4 & 8 & 0 \\
\hline
\end{tabular}


Appendix 1. Continued.

\begin{tabular}{|c|c|c|c|c|c|c|c|c|c|c|c|c|c|}
\hline \multirow{2}{*}{ Taxon } & \multirow{2}{*}{ Status } & \multirow{2}{*}{$\begin{array}{c}\mathrm{N} \\
\text { Points }\end{array}$} & \multirow{2}{*}{$\stackrel{\mathrm{N}}{\text { Habitats }}$} & \multirow{2}{*}{ Abund } & \multirow{2}{*}{ Dry } & \multirow{2}{*}{ Rai } & \multirow{2}{*}{ Run } & \multicolumn{6}{|c|}{ Habitat } \\
\hline & & & & & & & & LAN & COR & MUR & CUL & BORD & BORD1 \\
\hline Amazona amazonica (Linnaeus, 1766) & $\mathrm{R}$ & 3 & 3 & 19 & & $x$ & & 0 & 12 & 5 & 2 & 0 & 0 \\
\hline \multicolumn{14}{|l|}{ Cuculiforme } \\
\hline \multicolumn{14}{|l|}{ Cuculidae } \\
\hline Piaya cayana (Linnaeus, 1766) & $\mathrm{R}$ & 3 & 3 & 3 & $x$ & $x$ & & 1 & 1 & 1 & 0 & 0 & 0 \\
\hline Crotophaga major Gmelin, 1788 & M & 3 & 3 & 16 & & $x$ & & 2 & 6 & 8 & 0 & 0 & 0 \\
\hline Crotophaga ani Linnaeus, 1758 & $\mathrm{R}$ & 11 & 3 & 91 & $x$ & $x$ & $x$ & 0 & 21 & 29 & 41 & 0 & 0 \\
\hline Guira guira (Gmelin, 1788) & $\mathrm{R}$ & 16 & 4 & 58 & $x$ & $x$ & $x$ & 3 & 2 & 18 & 33 & 2 & 0 \\
\hline Tapera naevia (Linnaeus, 1766) & M & 1 & border & 1 & $x$ & & & 0 & 0 & 0 & 0 & 0 & 1 \\
\hline \multicolumn{14}{|l|}{ Apodiformes } \\
\hline \multicolumn{14}{|l|}{ Trochilidae } \\
\hline Glaucis hirsutus (Gmelin, 1788) & $\mathrm{R}$ & 6 & 2 & 7 & $x$ & $x$ & $x$ & 2 & 0 & 5 & 0 & 0 & 0 \\
\hline Phaethornis nattereri Berlepsch, 1887 & M & 2 & 2 & 2 & & $x$ & $x$ & 1 & 0 & 1 & 0 & 0 & 0 \\
\hline Phaethornis ruber (Linnaeus, 1758) & $\mathrm{R}$ & 1 & 1 & 1 & $x$ & & & 1 & 0 & 0 & 0 & 0 & 0 \\
\hline Phaethornis pretrei (Lesson \& Delattre, 1839) & M & 1 & 1 & 1 & $x$ & & & 1 & 0 & 0 & 0 & 0 & 0 \\
\hline Eupetomena macroura (Gmelin, 1788) & $\mathrm{R}$ & 8 & 3 & 11 & $x$ & $x$ & $x$ & 0 & 2 & 7 & 2 & 0 & 0 \\
\hline Anthracothorax nigricollis (Vieillot, 1817) & M & 2 & 2 & 2 & $x$ & & $x$ & 0 & 0 & 1 & 1 & 0 & 0 \\
\hline Chrysolampis mosquitus (Linnaeus, 1758) & M & 2 & 1 & 2 & & $x$ & $x$ & 0 & 2 & 0 & 0 & 0 & 0 \\
\hline Hylocharis chrysura (Shaw, 1812) & $\mathrm{R}$ & 13 & 4 & 30 & $x$ & $x$ & $x$ & 1 & 6 & 14 & 4 & 2 & 3 \\
\hline Polytmus guainumbi (Pallas, 1764) & M & 3 & 2 & 7 & & $x$ & $x$ & 0 & 0 & 1 & 6 & 0 & 0 \\
\hline Amazilia versicolor (Vieillot, 1818) & M & 1 & 1 & 2 & $x$ & & & 0 & 0 & 2 & 0 & 0 & 0 \\
\hline Amazilia fimbriata (Gmelin, 1788) & $\mathrm{R}$ & 27 & 4 & 98 & $x$ & $x$ & $x$ & 14 & 23 & 42 & 8 & 7 & 4 \\
\hline Heliomaster furcifer (Shaw, 1812) & M & 1 & 1 & 1 & & & $x$ & 0 & 1 & 0 & 0 & 0 & 0 \\
\hline \multicolumn{14}{|l|}{ Trogoniformes } \\
\hline \multicolumn{14}{|l|}{ Trogonidae } \\
\hline Trogon curucui Linnaeus, 1766 & $\mathrm{R}$ & 4 & 2 & 10 & $\mathrm{x}$ & & & 6 & 0 & 2 & 0 & 0 & 2 \\
\hline \multicolumn{14}{|l|}{ Coraciiformes } \\
\hline \multicolumn{14}{|l|}{ Alcedinidae } \\
\hline Megaceryle torquata (Linnaeus, 1766) & $\mathrm{R}$ & 6 & 3 & 12 & & $x$ & $x$ & 6 & 0 & 2 & 2 & 0 & 2 \\
\hline Chloroceryle amazona (Latham, 1790) & M & 2 & 2 & 2 & & $x$ & $x$ & 0 & 0 & 1 & 1 & 0 & 0 \\
\hline Chloroceryle aenea (Pallas, 1764) & M & 8 & 3 & 12 & & $x$ & $x$ & 6 & 0 & 3 & 2 & 0 & 1 \\
\hline Chloroceryle americana (Gmelin, 1788) & M & 5 & 4 & 7 & & $x$ & $x$ & 3 & 1 & 1 & 2 & 0 & 0 \\
\hline Chloroceryle inda (Linnaeus, 1766) & M & 7 & 2 & 11 & & $x$ & $x$ & 4 & 0 & 3 & 0 & 1 & 3 \\
\hline \multicolumn{14}{|l|}{ Momotidae } \\
\hline Momotus momota (Linnaeus, 1766) & M & 1 & 1 & 1 & $\mathrm{x}$ & & & 0 & 0 & 1 & 0 & 0 & 0 \\
\hline \multicolumn{14}{|l|}{ Galbuliformes } \\
\hline Galbulidae & & & & & & & & & & & & & \\
\hline Galbula ruficauda Cuvier, 1816 & $\mathrm{R}$ & 4 & 2 & 8 & $x$ & $x$ & $x$ & 1 & 0 & 3 & 0 & 1 & 3 \\
\hline Bucconidae & & & & & & & & & & & & & \\
\hline Nystalus maculatus (Gmelin, 1788) & M & 5 & 2 & 7 & $x$ & $x$ & & 2 & 0 & 4 & 0 & 1 & 0 \\
\hline Monasa nigrifrons (Spix, 1824) & $\mathrm{R}$ & 8 & 3 & 28 & $x$ & $x$ & $x$ & 5 & 1 & 16 & 0 & 0 & 6 \\
\hline Piciformes Meyer \& Wolf, 1810 & & & & & & & & & & & & & \\
\hline Ramphastidae Vigors, 1825 & & & & & & & & & & & & & \\
\hline Ramphastos toco Statius Muller, 1776 & $\mathrm{R}$ & 12 & 3 & 20 & $x$ & & & 0 & 2 & 9 & 7 & 0 & 2 \\
\hline Pteroglossus castanotis Gould, 1834 & $\mathrm{R}$ & 2 & 2 & 6 & $x$ & $x$ & & 4 & 0 & 2 & 0 & 0 & 0 \\
\hline
\end{tabular}


Appendix 1. Continued.

\begin{tabular}{|c|c|c|c|c|c|c|c|c|c|c|c|c|c|}
\hline \multirow{2}{*}{ Taxon } & \multirow{2}{*}{ Status } & \multirow{2}{*}{$\begin{array}{c}\mathrm{N} \\
\text { Points }\end{array}$} & \multirow{2}{*}{$\stackrel{\mathrm{N}}{\text { Habitats }}$} & \multirow{2}{*}{ Abund } & \multirow{2}{*}{ Dry } & \multirow{2}{*}{ Rai } & \multirow{2}{*}{ Run - } & \multicolumn{6}{|c|}{ Habitat } \\
\hline & & & & & & & & LAN & COR & MUR & CUL E & BORD & BORD1 \\
\hline \multicolumn{14}{|l|}{ Picidae Leach, 1820} \\
\hline Picumnus albosquamatus d'Orbigny, 1840 & $\mathrm{R}$ & 22 & 3 & 67 & $x$ & $x$ & $x$ & 14 & 8 & 31 & 0 & 9 & 5 \\
\hline Melanerpes candidus (Otto, 1796) & M & 4 & 2 & 6 & $\mathrm{x}$ & & & 0 & 0 & 4 & 1 & 1 & 0 \\
\hline Veniliornis passerinus (Linnaeus, 1766) & $\mathrm{R}$ & 8 & 3 & 16 & $x$ & $x$ & $x$ & 0 & 2 & 9 & 1 & 4 & 0 \\
\hline Colaptes campestris (Vieillot, 1818) & M & 9 & 2 & 15 & $x$ & & $x$ & 0 & 0 & 10 & 3 & 2 & 0 \\
\hline Celeus lugubris (Malherbe, 1851) & $\mathrm{R}$ & 14 & 4 & 31 & $x$ & $x$ & $\mathrm{x}$ & 11 & 5 & 8 & 1 & 2 & 4 \\
\hline Dryocopus lineatus (Linnaeus, 1766) & $\mathrm{R}$ & 3 & 3 & 4 & $x$ & $x$ & & 1 & 0 & 2 & 1 & 0 & 0 \\
\hline Campephilus melanoleucos (Gmelin, 1788) & M & 4 & 2 & 6 & $x$ & & $x$ & 0 & 0 & 1 & 2 & 3 & 0 \\
\hline \multicolumn{14}{|l|}{ Passeriformes Linné, 1758} \\
\hline \multicolumn{14}{|l|}{ Thamnophilidae Swainson, 1824} \\
\hline Taraba major (Vieillot, 1816) & $\mathrm{R}$ & 5 & 3 & 10 & & $\mathrm{x}$ & $\mathrm{x}$ & 1 & 3 & 3 & 0 & 0 & 3 \\
\hline Thamnophilus doliatus (Linnaeus, 1764) & $\mathrm{R}$ & 5 & 3 & 6 & $x$ & $x$ & $x$ & 2 & 0 & 2 & 1 & 1 & 0 \\
\hline Thamnophilus pelzelni Hellmayr, 1924 & $\mathrm{R}$ & 4 & 2 & 11 & $x$ & $x$ & $x$ & 6 & 0 & 4 & 0 & 1 & 0 \\
\hline Herpsilochmus longirostris Pelzeln, 1868 & $\mathrm{R}$ & 6 & 2 & 31 & $x$ & $x$ & $x$ & 27 & 0 & 4 & 0 & 0 & 0 \\
\hline Formicivora rufa (Wied, 1831) & $\mathrm{R}$ & 21 & 4 & 91 & $\mathrm{x}$ & $\mathrm{x}$ & $\mathrm{x}$ & 3 & 28 & 45 & 2 & 13 & 0 \\
\hline Cercomacra melanaria (Ménétriès, 1835) & $\mathrm{R}$ & 2 & 1 & 9 & $x$ & $x$ & $x$ & 9 & 0 & 0 & 0 & 0 & 0 \\
\hline Hypocnemoides maculicauda (Pelzeln, 1868) & $\mathrm{R}$ & 1 & 1 & 5 & & $x$ & $x$ & 5 & 0 & 0 & 0 & 0 & 0 \\
\hline \multicolumn{14}{|l|}{ Dendrocolaptidae Gray, 1840} \\
\hline Sittasomus griseicapillus (Vieillot, 1818) & $\mathrm{R}$ & 9 & 4 & 15 & $\mathrm{x}$ & $\mathrm{x}$ & $\mathrm{x}$ & 1 & 5 & 3 & 1 & 5 & 0 \\
\hline Xiphocolaptes major (Vieillot, 1818) & $\mathrm{R}$ & 7 & 4 & 12 & $\mathrm{x}$ & $\mathrm{x}$ & $\mathrm{x}$ & 1 & 1 & 8 & 2 & 0 & 0 \\
\hline Xiphorhynchus picus (Gmelin, 1788) & $\mathrm{R}$ & 10 & 2 & 23 & $x$ & $x$ & $x$ & 14 & 0 & 8 & 0 & 0 & 1 \\
\hline Xiphorhynchus guttatus (Lichtenstein, 1820) & M & 1 & border & 3 & $x$ & & $\mathrm{x}$ & 0 & 0 & 0 & 0 & 0 & 3 \\
\hline Lepidocolaptes angustirostris (Vieillot, 1818) & $\mathrm{R}$ & 24 & 4 & 74 & $x$ & $\mathrm{x}$ & $x$ & 3 & 14 & 48 & 2 & 5 & 2 \\
\hline Campylorhamphus trochilirostris (Lichtenstein, 1820) & M & 2 & 2 & 2 & $x$ & & $x$ & 1 & 1 & 0 & 0 & 0 & 0 \\
\hline \multicolumn{14}{|l|}{ Furnariidae Gray, 1840} \\
\hline Furnarius leucopus Swainson, 1838 & $\mathrm{R}$ & 10 & 3 & 27 & $x$ & $x$ & $x$ & 14 & 0 & 5 & 6 & 0 & 2 \\
\hline Furnarius rufus (Gmelin, 1788) & $\mathrm{R}$ & 14 & 3 & 61 & $x$ & $x$ & $x$ & 0 & 8 & 28 & 25 & 0 & 0 \\
\hline Synallaxis frontalis Pelzeln, 1859 & M & 1 & 1 & 1 & & & $x$ & 0 & 0 & 1 & 0 & 0 & 0 \\
\hline Synallaxis albilora Pelzeln, 1856 & $\mathrm{R}$ & 15 & 3 & 67 & $x$ & $x$ & $x$ & 29 & 0 & 27 & 3 & 2 & 6 \\
\hline Cranioleuca vulpina (Pelzeln, 1856) & $\mathrm{R}$ & 2 & 2 & 8 & & $x$ & $x$ & 2 & 0 & 0 & 6 & 0 & 0 \\
\hline Certhiaxis cinnamomeus (Gmelin, 1788) & $\mathrm{R}$ & 2 & 2 & 5 & & $\mathrm{x}$ & & 0 & 3 & 0 & 2 & 0 & 0 \\
\hline Phacellodomus ruber (Vieillot, 1817) & $\mathrm{R}$ & 5 & 2 & 10 & $x$ & $\mathrm{x}$ & & 0 & 0 & 6 & 4 & 0 & 0 \\
\hline Pseudoseisura unirufa (d'Orbigny \& Lafresnaye, 1838) & $\mathrm{R}$ & 5 & 2 & 10 & $x$ & & $x$ & 0 & 0 & 4 & 5 & 1 & 0 \\
\hline \multicolumn{14}{|l|}{ Tyrannidae Vigors, 1825} \\
\hline Hemitriccus margaritaceiventer (d'Orbigny \& Lafresnaye, 1837) & $\mathrm{R}$ & 20 & 3 & 103 & $x$ & $\mathrm{x}$ & $x$ & 20 & 17 & 44 & 0 & 20 & 2 \\
\hline Poecilotriccus latirostris (Pelzeln, 1868) & $\mathrm{R}$ & 3 & 2 & 7 & $x$ & $x$ & $\mathrm{x}$ & 6 & 0 & 1 & 0 & 0 & 0 \\
\hline Todirostrum cinereum (Linnaeus, 1766) & $\mathrm{R}$ & 2 & 2 & 4 & & $x$ & & 2 & 0 & 2 & 0 & 0 & 0 \\
\hline Myiopagis gaimardii (d'Orbigny, 1839) & $\mathrm{R}$ & 19 & 4 & 79 & $x$ & $x$ & $x$ & 28 & 3 & 27 & 3 & 16 & 2 \\
\hline Myiopagis viridicata (Vieillot, 1817) & $\mathrm{R}$ & 8 & 2 & 13 & $x$ & $x$ & $x$ & 3 & 0 & 10 & 0 & 0 & 0 \\
\hline Elaenia flavogaster (Thunberg, 1822) & M & 11 & 3 & 19 & $x$ & $x$ & $x$ & 2 & 0 & 10 & 7 & 0 & 0 \\
\hline Elaenia albiceps (d'Orbigny \& Lafresnaye, 1837) & M & 3 & 2 & 6 & $x$ & & $\mathrm{x}$ & 4 & 2 & 0 & 0 & 0 & 0 \\
\hline Elaenia cristata Pelzeln, 1868 & M & 1 & 1 & 1 & $x$ & & & 0 & 0 & 1 & 0 & 0 & 0 \\
\hline Camptostoma obsoletum (Temminck, 1824) & $\mathrm{R}$ & 23 & 4 & 72 & $x$ & $x$ & $\mathrm{x}$ & 4 & 2 & 45 & 9 & 12 & 0 \\
\hline
\end{tabular}


Appendix 1. Continued.

\begin{tabular}{|c|c|c|c|c|c|c|c|c|c|c|c|c|c|}
\hline \multirow{2}{*}{ Taxon } & \multirow{2}{*}{ Status } & \multirow{2}{*}{$\begin{array}{c}\mathrm{N} \\
\text { Points }\end{array}$} & \multirow{2}{*}{$\begin{array}{c}\mathrm{N} \\
\text { Habitats }\end{array}$} & \multirow{2}{*}{ Abund } & \multirow{2}{*}{ Dry } & \multirow{2}{*}{ Rai } & \multirow{2}{*}{ Run - } & \multicolumn{6}{|c|}{ Habitat } \\
\hline & & & & & & & & LAN & COR & MUR & CUL & BORD & BORD1 \\
\hline Suiriri islerorum Zimmer, Whittaker \& Oren, 2001 & M & 2 & 2 & 2 & $\mathrm{x}$ & & & 0 & 0 & 1 & 1 & 0 & 0 \\
\hline Phaeomyias murina (Spix, 1825) & M & 2 & 1 & 2 & $x$ & & & 0 & 0 & 1 & 0 & 1 & 0 \\
\hline Euscarthmus meloryphus Wied, 1831 & $\mathrm{R}$ & 7 & 3 & 11 & $\mathrm{x}$ & & $\mathrm{x}$ & 3 & 4 & 3 & 0 & 1 & 0 \\
\hline Sublegatus modestus (Wied, 1831) & M & 4 & 1 & 15 & $x$ & $x$ & $x$ & 0 & 0 & 4 & 0 & 2 & 9 \\
\hline Tolmomyias sulphurescens (Spix, 1825) & $\mathrm{R}$ & 3 & 1 & 10 & $x$ & $x$ & $x$ & 1 & 0 & 0 & 0 & 8 & 1 \\
\hline Cnemotriccus fuscatus (Wied, 1831) & $\mathrm{R}$ & 18 & 4 & 62 & $x$ & $x$ & $x$ & 26 & 2 & 25 & 2 & 3 & 4 \\
\hline Xolmis velatus (Lichtenstein, 1823) & $\mathrm{R}$ & 6 & 2 & 11 & $x$ & $x$ & $x$ & 0 & 0 & 3 & 8 & 0 & 0 \\
\hline Machetornis rixosa (Vieillot, 1819) & $\mathrm{R}$ & 5 & 3 & 21 & $x$ & $x$ & $x$ & 0 & 5 & 3 & 13 & 0 & 0 \\
\hline Legatus leucophaius (Vieillot, 1818) & $\mathrm{R}$ & 3 & 1 & 3 & $x$ & & & 0 & 0 & 2 & 0 & 1 & 0 \\
\hline Myiozetetes cayanensis (Linnaeus, 1766) & $\mathrm{R}$ & 5 & 3 & 21 & $x$ & $x$ & $x$ & 2 & 0 & 9 & 3 & 0 & 7 \\
\hline Myiozetetes similis (Spix, 1825) & $\mathrm{R}$ & 1 & 1 & 1 & $x$ & $x$ & & 0 & 1 & 0 & 0 & 0 & 0 \\
\hline Pitangus sulphuratus (Linnaeus, 1766) & $\mathrm{R}$ & 24 & 4 & 102 & $x$ & $x$ & $x$ & 6 & 8 & 47 & 30 & 6 & 5 \\
\hline Philohydor lictor (Lichtenstein, 1823) & $\mathrm{R}$ & 8 & 4 & 21 & $x$ & $x$ & $x$ & 5 & 1 & 6 & 3 & 4 & 2 \\
\hline Myiodynastes maculatus (Statius Muller, 1776) & $\mathrm{R}$ & 6 & 3 & 9 & $x$ & $x$ & $x$ & 0 & 1 & 4 & 4 & 0 & 0 \\
\hline Megarynchus pitangua (Linnaeus, 1766) & $\mathrm{R}$ & 15 & 3 & 30 & $x$ & $x$ & $x$ & 4 & 0 & 21 & 1 & 1 & 3 \\
\hline Tyrannus albogularis Burmeister, 1856 & M & 1 & 1 & 2 & $x$ & $x$ & & 0 & 0 & 2 & 0 & 0 & 0 \\
\hline Tyrannus melancholicus Vieillot, 1819 & $\mathrm{R}$ & 1 & border & 1 & $x$ & & & 0 & 0 & 0 & 0 & 1 & 0 \\
\hline Casiornis rufus (Vieillot, 1816) & $\mathrm{R}$ & 20 & 3 & 60 & $x$ & $x$ & $\mathrm{x}$ & 11 & 6 & 30 & 0 & 10 & 3 \\
\hline Myiarchus swainsoni Cabanis \& Heine, 1859 & M & 9 & 3 & 18 & $x$ & $x$ & $x$ & 4 & 5 & 9 & 0 & 0 & 0 \\
\hline Myiarchus ferox (Gmelin, 1789) & $\mathrm{R}$ & 27 & 4 & 87 & $x$ & $x$ & $\mathrm{x}$ & 14 & 13 & 41 & 10 & 6 & 3 \\
\hline Myiarchus tyrannulus (Statius Muller, 1776) & $\mathrm{R}$ & 23 & 4 & 82 & $x$ & $x$ & $x$ & 9 & 7 & 54 & 1 & 7 & 4 \\
\hline \multicolumn{14}{|l|}{ Pipridae Rafinesque, 1815} \\
\hline Neopelma pallescens (Lafresnaye, 1853) & $\mathrm{R}$ & 2 & 1 & 6 & $x$ & $x$ & $x$ & 6 & 0 & 0 & 0 & 0 & 0 \\
\hline Antilophia galeata (Lichtenstein, 1823) & $\mathrm{R}$ & 2 & 1 & 6 & $x$ & $x$ & $x$ & 6 & 0 & 0 & 0 & 0 & 0 \\
\hline \multicolumn{14}{|l|}{ Tityridae Gray, 1840} \\
\hline Tityra inquisitor (Lichtenstein, 1823) & M & 3 & 2 & 4 & $\mathrm{x}$ & & $x$ & 2 & 0 & 2 & 0 & 0 & 0 \\
\hline Tityra cayana (Linnaeus, 1766) & $\mathrm{R}$ & 9 & 3 & 11 & $x$ & $x$ & $x$ & 2 & 0 & 4 & 1 & 3 & 1 \\
\hline Pachyramphus viridis (Vieillot, 1816) & M & 6 & 1 & 10 & $x$ & & & 0 & 0 & 8 & 0 & 1 & 1 \\
\hline Pachyramphus marginatus (Lichtenstein, 1823) & $\mathrm{R}$ & 6 & 3 & 9 & $x$ & $x$ & $x$ & 2 & 2 & 4 & 0 & 1 & 0 \\
\hline \multicolumn{14}{|l|}{ Vireonidae Swainson, 1837} \\
\hline Cyclarhis gujanensis (Gmelin, 1789) & $\mathrm{R}$ & 2 & 1 & 5 & $x$ & $x$ & $x$ & 0 & 0 & 5 & 0 & 0 & 0 \\
\hline Vireo olivaceus (Linnaeus, 1766) & $\mathrm{R}$ & 3 & 2 & 14 & $x$ & $x$ & & 11 & 0 & 3 & 0 & 0 & 0 \\
\hline Hylophilus pectoralis Sclater, 1866 & $\mathrm{R}$ & 3 & 2 & 7 & $x$ & & $x$ & 6 & 0 & 1 & 0 & 0 & 0 \\
\hline \multicolumn{14}{|l|}{ Corvidae Leach, 1820} \\
\hline Cyanocorax cyanomelas (Vieillot, 1818) & $\mathrm{R}$ & 23 & 4 & 102 & $\mathrm{x}$ & $x$ & $x$ & 16 & 13 & 53 & 4 & 8 & 8 \\
\hline \multicolumn{14}{|l|}{ Troglodytidae Swainson, 1831} \\
\hline Troglodytes musculus Naumann, 1823 & $\mathrm{R}$ & 10 & 3 & 21 & $\mathrm{x}$ & $x$ & $x$ & 0 & 4 & 6 & 10 & 1 & 0 \\
\hline Campylorhynchus turdinus (Wied, 1831) & $\mathrm{R}$ & 9 & 3 & 43 & $x$ & $x$ & $x$ & 0 & 14 & 15 & 8 & 0 & 6 \\
\hline Pheugopedius genibarbis (Swainson, 1838) & $\mathrm{R}$ & 2 & 1 & 2 & & $\mathrm{x}$ & & 0 & 1 & 0 & 0 & 0 & 1 \\
\hline \multicolumn{14}{|l|}{ Donacobiidae } \\
\hline Donacobius atricapilla (Linnaeus, 1766) & $\mathrm{R}$ & 1 & 1 & 1 & & $x$ & & 0 & 0 & 0 & 1 & 0 & 0 \\
\hline \multicolumn{14}{|l|}{ Polioptilidae } \\
\hline Polioptila dumicola (Vieillot, 1817) & $\mathrm{R}$ & 19 & 4 & 143 & $x$ & $x$ & $x$ & 25 & 14 & 73 & 2 & 29 & 0 \\
\hline
\end{tabular}


Appendix 1. Continued.

\begin{tabular}{|c|c|c|c|c|c|c|c|c|c|c|c|c|c|}
\hline \multirow{2}{*}{ Taxon } & \multirow{2}{*}{ Status } & \multirow{2}{*}{$\begin{array}{c}\mathrm{N} \\
\text { Points }\end{array}$} & \multirow{2}{*}{$\begin{array}{c}\mathrm{N} \\
\text { Habitats }\end{array}$} & \multirow{2}{*}{ Abund } & \multirow{2}{*}{ Dry } & \multirow{2}{*}{ Rai } & \multirow{2}{*}{ Run } & \multicolumn{6}{|c|}{ Habitat } \\
\hline & & & & & & & & LAN & COR & MUR & CUL & BORD & BORD1 \\
\hline \multicolumn{14}{|l|}{ Turdidae } \\
\hline Turdus leucomelas Vieillot, 1818 & M & 1 & 1 & 1 & $x$ & & & 0 & 0 & 1 & 0 & 0 & 0 \\
\hline Turdus amaurochalinus Cabanis, 1850 & $\mathrm{R}$ & 15 & 4 & 54 & $x$ & & $x$ & 32 & 1 & 15 & 1 & 3 & 2 \\
\hline \multicolumn{14}{|l|}{ Mimidae } \\
\hline Mimus saturninus (Lichtenstein, 1823) & $\mathrm{R}$ & 4 & 2 & 11 & $x$ & $x$ & $x$ & 0 & 0 & 1 & 10 & 0 & 0 \\
\hline \multicolumn{14}{|l|}{ Coerebidae } \\
\hline Coereba flaveola (Linnaeus, 1758) & $\mathrm{R}$ & 9 & 2 & 12 & $x$ & $x$ & & 4 & 0 & 8 & 0 & 0 & 0 \\
\hline \multicolumn{14}{|l|}{ Thraupidae } \\
\hline Nemosia pileata (Boddaert, 1783) & $\mathrm{R}$ & 3 & 2 & 7 & $x$ & $x$ & & 0 & 0 & 4 & 1 & 2 & 0 \\
\hline Cypsnagra hirundinacea (Lesson, 1831) & M & 1 & 1 & 3 & & & $x$ & 0 & 0 & 0 & 3 & 0 & 0 \\
\hline Ramphocelus carbo (Pallas, 1764) & $\mathrm{R}$ & 9 & 3 & 36 & $x$ & $\mathrm{x}$ & $x$ & 11 & 0 & 18 & 2 & 0 & 5 \\
\hline Thraupis sayaca (Linnaeus, 1766) & $\mathrm{R}$ & 15 & 4 & 57 & $x$ & $x$ & $x$ & 3 & 3 & 30 & 10 & 11 & 0 \\
\hline Thraupis palmarum (Wied, 1823) & $\mathrm{R}$ & 1 & 1 & 2 & $\mathrm{x}$ & $\mathrm{x}$ & & 0 & 0 & 2 & 0 & 0 & 0 \\
\hline Conirostrum speciosum (Temminck, 1824) & $\mathrm{R}$ & 19 & 3 & 113 & $x$ & $x$ & $x$ & 30 & 15 & 40 & 0 & 23 & 5 \\
\hline \multicolumn{14}{|l|}{ Emberizidae } \\
\hline Ammodramus humeralis (Bosc, 1792) & M & 13 & 3 & 95 & $x$ & & $x$ & 0 & 1 & 46 & 48 & 0 & 0 \\
\hline Sicalis flaveola (Linnaeus, 1766) & M & 4 & 3 & 5 & $x$ & & $x$ & 0 & 1 & 1 & 3 & 0 & 0 \\
\hline Emberizoides herbicola (Vieillot, 1817) & $\mathrm{R}$ & 4 & 2 & 10 & $x$ & $x$ & $x$ & 0 & 0 & 4 & 5 & 1 & 0 \\
\hline Volatinia jacarina (Linnaeus, 1766) & $\mathrm{R}$ & 19 & 4 & 97 & $x$ & & $x$ & 2 & 4 & 49 & 39 & 3 & 0 \\
\hline Sporophila collaris (Boddaert, 1783) & $\mathrm{R}$ & 5 & 3 & 12 & $x$ & $x$ & $x$ & 0 & 1 & 1 & 10 & 0 & 0 \\
\hline Sporophila angolensis (Linnaeus, 1766) & $\mathrm{R}$ & 9 & 3 & 25 & $x$ & $x$ & $x$ & 6 & 0 & 15 & 4 & 0 & 0 \\
\hline Coryphospingus cucullatus (Statius Muller, 1776) & $\mathrm{R}$ & 14 & 4 & 46 & $x$ & $x$ & $x$ & 3 & 13 & 20 & 2 & 8 & 0 \\
\hline Paroaria capitata (d'Orbigny \& Lafresnaye, 1837) & $\mathrm{R}$ & 10 & 3 & 38 & $x$ & $x$ & $x$ & 6 & 0 & 8 & 19 & 0 & 5 \\
\hline \multicolumn{14}{|l|}{ Cardinalidae } \\
\hline Saltator coerulescens Vieillot, 1817 & $\mathrm{R}$ & 1 & 1 & 3 & $x$ & $x$ & & 0 & 0 & 0 & 3 & 0 & 0 \\
\hline Saltator similis d'Orbigny \& Lafresnaye, 1837 & M & 1 & 1 & 1 & $\mathrm{x}$ & $\mathrm{x}$ & & 0 & 0 & 1 & 0 & 0 & 0 \\
\hline Saltator atricollis Vieillot, 1817 & M & 5 & 3 & 12 & $x$ & & $x$ & 1 & 0 & 5 & 5 & 1 & 0 \\
\hline \multicolumn{14}{|l|}{ Parulidae } \\
\hline Parula pitiayumi (Vieillot, 1817) & $\mathrm{R}$ & 5 & 3 & 9 & $x$ & $x$ & $x$ & 6 & 0 & 2 & 1 & 0 & 0 \\
\hline Basileuterus flaveolus (Baird, 1865) & $\mathrm{R}$ & 4 & 2 & 19 & $x$ & $x$ & $x$ & 16 & 0 & 3 & 0 & 0 & 0 \\
\hline \multicolumn{14}{|l|}{ Icteridae } \\
\hline Psarocolius decumanus (Pallas, 1769) & $\mathrm{R}$ & 20 & 4 & 52 & $x$ & $x$ & $\mathrm{x}$ & 8 & 3 & 28 & 1 & 10 & 2 \\
\hline Procacicus solitarius (Vieillot, 1816) & $\mathrm{R}$ & 3 & 2 & 5 & $x$ & $x$ & & 2 & 0 & 3 & 0 & 0 & 0 \\
\hline Cacicus cela (Linnaeus, 1758) & $\mathrm{R}$ & 4 & 3 & 12 & $x$ & & $x$ & 1 & 5 & 6 & 0 & 0 & 0 \\
\hline Icterus cayanensis (Linnaeus, 1766) & $\mathrm{R}$ & 12 & 4 & 27 & $x$ & $x$ & $x$ & 2 & 1 & 17 & 5 & 2 & 0 \\
\hline Icterus croconotus (Wagler, 1829) & $\mathrm{R}$ & 4 & 4 & 8 & $x$ & $x$ & $x$ & 2 & 2 & 3 & 1 & 0 & 0 \\
\hline Gnorimopsar chopi (Vieillot, 1819) & $\mathrm{R}$ & 9 & 2 & 35 & $x$ & $x$ & $x$ & 0 & 0 & 19 & 12 & 4 & 0 \\
\hline Agelaioides badius (Vieillot, 1819) & M & 2 & 2 & 7 & & $x$ & $x$ & 0 & 0 & 6 & 1 & 0 & 0 \\
\hline Molothrus oryzivorus (Gmelin, 1788) & M & 1 & 1 & 1 & $x$ & & & 0 & 0 & 1 & 0 & 0 & 0 \\
\hline Sturnella superciliaris (Bonaparte, 1850) & M & 1 & 1 & 1 & & & $x$ & 0 & 0 & 0 & 1 & 0 & 0 \\
\hline \multicolumn{14}{|l|}{ Fringillidae } \\
\hline Euphonia chlorotica (Linnaeus, 1766) & $\mathrm{R}$ & 8 & 3 & 14 & $x$ & $x$ & $x$ & 2 & 1 & 7 & 0 & 4 & 0 \\
\hline Total Abundance & & & & & & & & 611 & 411 & 1525 & 555 & 302 & 147 \\
\hline Total Abundance/N parcels & & & & & & & & 122.2 & 137 & 108.93 & 111 & 151 & 147 \\
\hline Species richness & & & & & & & & 92 & 66 & 137 & 92 & 58 & 46 \\
\hline Average species richness & & & & & & & & 41 & 34.3 & 38.1 & 33.8 & 41.5 & 46 \\
\hline $\mathrm{N}$ parcels & & & & & & & & 5 & 3 & 14 & 5 & 2 & 1 \\
\hline
\end{tabular}

